\title{
Transatlantica
}

Revue d'études américaines. American Studies Journal

$2 \mid 2014$

Aesthetics of Theory in the Modern Era and Beyond / Photographie documentaire

\section{Twelve Million Black Voices: Let Us Now Hear Black Voices}

\section{Laurence Cossu-Beaumont}

\section{(2) OpenEdition}

Journals

Electronic version

URL: https://journals.openedition.org/transatlantica/7232

DOI: $10.4000 /$ transatlantica. 7232

ISSN: 1765-2766

\section{Publisher}

Association française d'Etudes Américaines (AFEA)

\section{Electronic reference}

Laurence Cossu-Beaumont, "Twelve Million Black Voices: Let Us Now Hear Black Voices", Transatlantica [Online], 2 | 2014, Online since 06 March 2015, connection on 01 February 2023. URL: http://

journals.openedition.org/transatlantica/7232 ; DOI: https://doi.org/10.4000/transatlantica.7232

This text was automatically generated on 1 February 2023.

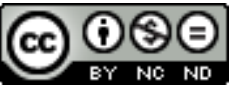

Creative Commons - Attribution-NonCommercial-NoDerivatives 4.0 International - CC BY-NC-ND 4.0

https://creativecommons.org/licenses/by-nc-nd/4.0/ 


\title{
Twelve Million Black Voices: Let Us Now Hear Black Voices
}

\author{
Laurence Cossu-Beaumont
}

\section{Introduction}

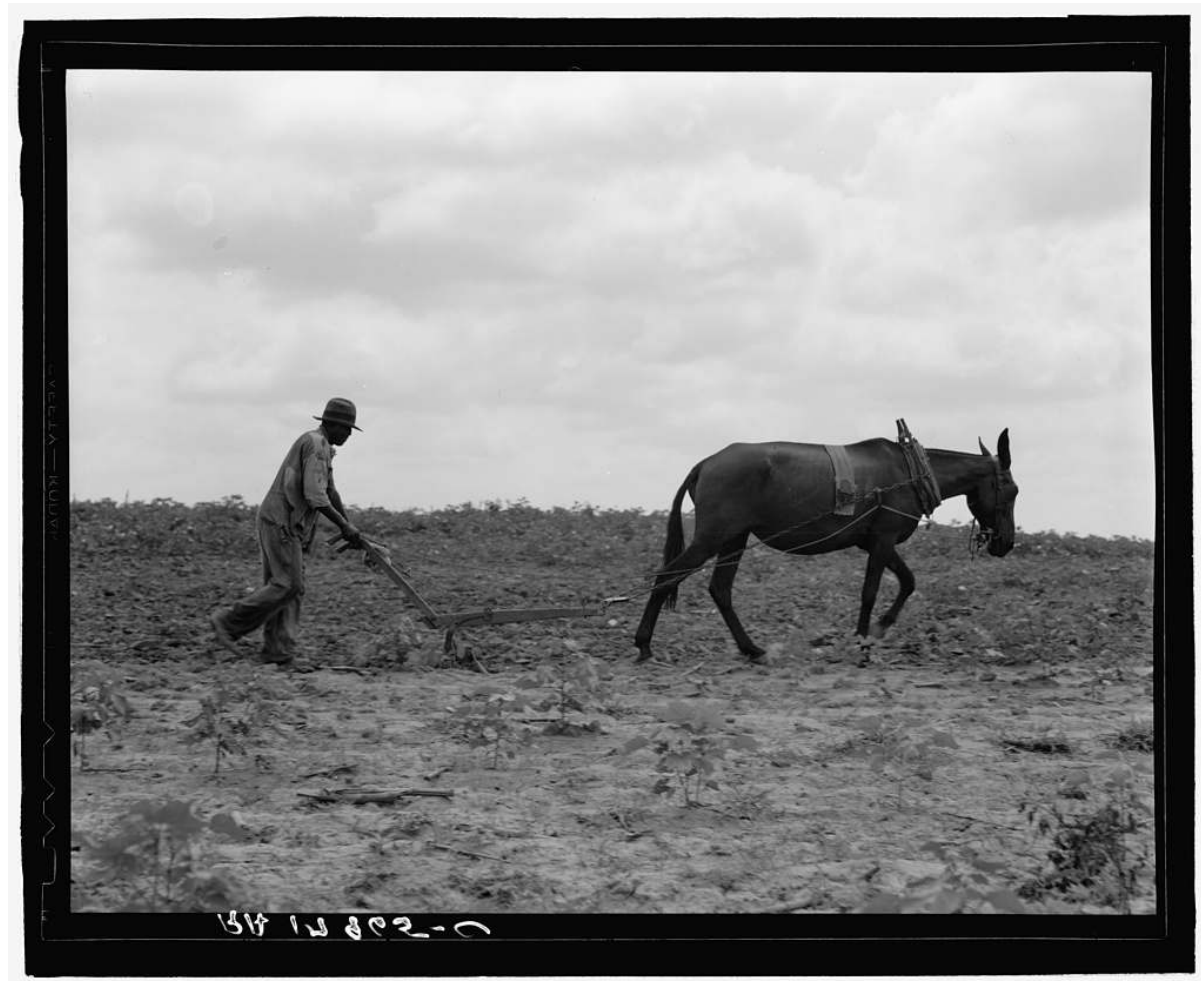

DOROTHEA LANgE, WE PLOW AND PLANT COTTON ${ }^{1}$

Let Us Now Hear Black Voices. Such could be an adequate subtitle for Twelve Million Black Voices, a 1941 collection of photographs, selected from the Farm Security Administration 
files by FSA-employed photographer Edwin Rosskam and accompanied by Richard Wright's texts. Both books were published in 1941, both rely on photographs by Walker Evans-one of them is the exact same-and stem from the work of Farm Security Administration (FSA) photographers. Both books are of course a collection of photographs accompanied by a powerful text and present a tension on the page between image and fact ${ }^{2}$ on the one hand, and aesthetics and politics on the other.

Between 1935 and 1942, photographers working for the FSA, more specifically for the Historical Section, collected about sixty thousand photographs of American life in the countryside and cities with topics ranging from housing and farming to Americans at work, at home, or at leisure under the direction of Roy Stryker. Rexford Tugwell, who had been Stryker's professor of economics and mentor at Columbia, and was now head of the Resettlement Administration (soon-to-be FSA ${ }^{3}$ ), handed his former teaching assistant a strategic position within the Information Division of the Resettlement Administration: the Historical Section was in charge of contributing material to present "the agency's positive programs and accomplishments to the country" (Hurley, 1972, 34). Yet this administration with a government agenda produced an exceptional legacy beyond the immediate propagandistic purposes. Stryker was quite familiar with the use of photography in political, economic and educational contexts as he had been the illustration editor for Tugwell's American Economic Life and the Means of its Improvement, a study the latter co-authored with Thomas Munro in 1925. On that occasion, as well as for the updated editions, Stryker worked in close collaboration with Lewis Hine and later discovered the work of Margaret Bourke-White (Hurley, 1972, 14-15). Once appointed at the FSA's Historical Section he brought on board Jack Delano, Dorothea Lange, Russell Lee, Carl Mydans, Arthur Rothstein, Edwin Rosskam, Ben Shahn, John Vachon, Marion Post Wolcott and Gordon Park. ${ }^{4}$ Stryker was thus the one who turned the thereafter ill-named Historical Section into a photographic unit whose ambitious and relentless work he defined almost on his own terms. ${ }^{5}$ Under his authority, the photographers were to achieve an unprecedented legacy that is celebrated to this day. Newhall Beaumont, first curator of photography of the New York Museum of Modern Art as of 1940 , generally hailed the first historian of photography, reflected back in the 1980s that though "Documentary photography is a term that has defied definition ever since it was introduced in the 1930s", there seems to be an understanding that documentary photography is best embodied by the FSA legacy: "The extraordinary photographic work done between 1935 and 1943 by the Historical Section of the United States Government's Farm Security Administration is considered the classical documentation of the depression era" (Newhall, 1984, 1-2).

3 How the FSA photographers of the Historical Section thus recorded the reality of 1930 s America in their documentary endeavor is a starting point for this paper whose aim is to (re)consider one object among the many that stemmed from the FSA photographic endeavor: Twelve Million Black Voices. Twelve Million Black Voices displays portraits and visual representations of the lives of the twelve million invisible black Americans and releases a protesting voice for the twelve million silent black Americans. The book is both an expected product of a documentary decade and an original project and legacy: the visual icons of 1930s photography were-and still are-the Migrant Mother or the Okie tenant, in other words, white faces, ${ }^{6}$ while Twelve Million Black Voices featured a black child's close-up portrait on its original cover and assembled close to ninety photographs of African Americans. 


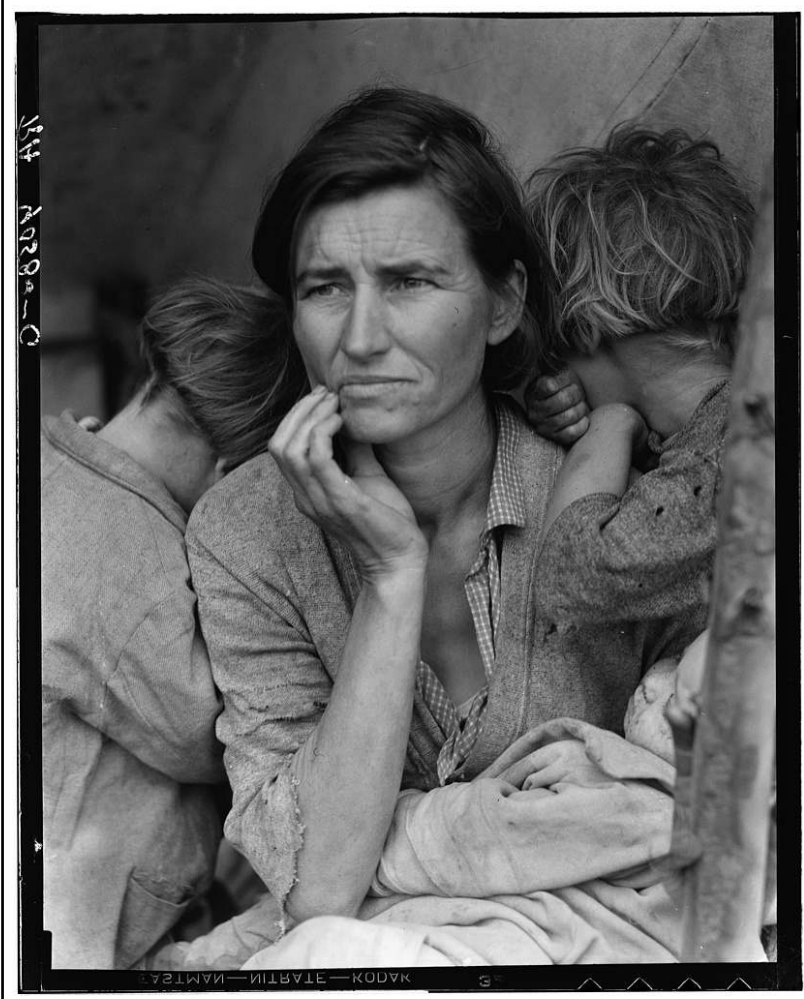

DOROTHEA LANgE, MIgRANT MOTHER

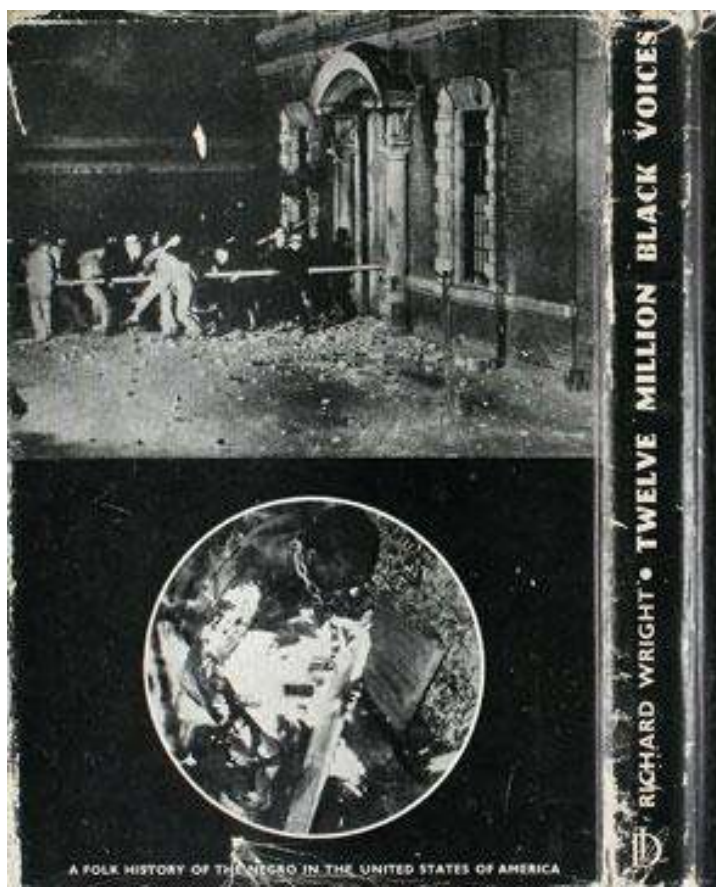

RICHARD WRIGHT

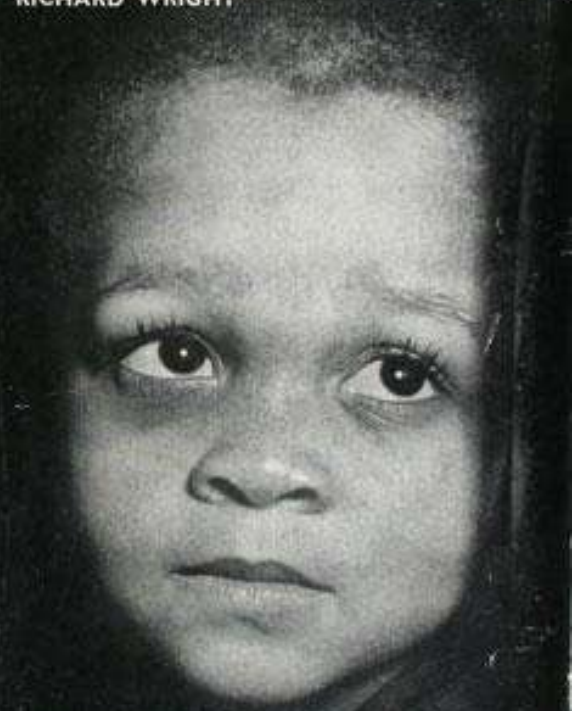

TWELVE MILLION $B \square A \mathbb{C} R$ V O IC E S

ORIgINAL 1941 COVER OF TWELVE MILLION BLACK VOICES ${ }^{7}$

4 More importantly, while FSA photographers endeavored at "documenting"-in Newhall's terms-the reality of Great Depression America, they also admittedly strove at expressing important "truths" about life in America-in Stange's terms below. 
The vast majority of pictures in the FSA file [...] remain richly informative about the country in those years. They bear witness not only to material conditions, but also to the photographers' determination to record and express important social and cultural truths, including the changes they perceived as industrialization and urban and suburban migration intensified, and defense industries expanded. (Stange, 2003, xv)

5 So while Twelve Million Black Voices offered a rare representation of black life in America, how did it address the suggested agenda of "important social and cultural truths" ? The documentary spirit of the decade seemed to entail that "the fact, as we feel it, is commensurate with reality, and that our feeling of this fact, "without either dissection into science or digestion into art,' is an experience of truth" (Godine, 1980, 201). If the fact only, the raw unmediated image is the powerful vector of social and cultural truth in the spirit of 1930s documentary photography, then what is to be made of the narrative in Twelve Million Black Voices?

6 This paper will start from the frame of American documentary photography and how it aimed at speaking the truth by both exposing facts and expressing the era's inconvenient truths and will examine the specificity of Twelve Million Black Voices with its added narrative. The first part of this paper will consider the the collaboration that led to the publication of a photo-text book on black life in a decade of "documentary expression" and of "documentary imagination" (Stott, 1973, 119). The second part will reflect on how the widespread publication of photographs of black Americans may have allowed to expose the reality of Black life in America and may now provide a valuable source for scholars of the Great Migration, the Great Depression and African-American history. Ultimately the paper will engage a reflection on the narrative offered in Twelve Million Black Voices, a "folk history" carefully crafted, or perhaps staged, by the weaving of text and pictures. This paper thus strives to articulate the recording of 1930s reality and the exposure of racial discrimination, the aesthetic vision of FSA photographers and the protest narrative unfolded by Wright.

\section{Shooting the Great Depression in black-and-white: hiding the truth}

7 According to the only book-length study of black representation in the FSA archive, Nicholas Natanson's The Black Image in the New Deal (1992), 10.1 percent “included discernible black figures or their dwellings" (Natanson, 1992, 66), an exceptional representation considering that no encouragement was provided to photographers to specifically focus on African American subjects and characters:8 "Against administrative odds the photographers collectively achieved a range and depth of black coverage that was rare in government or private photography" (Natanson, 1992, 84). Consequently, the FSA fund, currently available at the Library of Congress, stands out as an exceptional legacy for the study of 1930s America and of the African American community in daily, work and home situations. Richard Wright reflected upon his discovery of the FSA archives in a 1941 interview: "it is one of the most remarkable collections in existence I think. If you want to get a comprehensive picture of our country, you should go through these files sometime. It's quite an education" (Kinnamon, 1993, 43). 
Interestingly enough, these images of black life were little used in the newspapers and magazines the FSA supplied, and in the exhibitions and travelling shows that were set up with the active collaboration of the FSA photo unit, notably of Edwin Rosskam. Rosskam was hired by Stryker in 1938: “That's what Roy had hired me for, to take a dent in the world. We sent a stream of pictures into that world via magazines and traveling exhibitions and, probably most important historically, in books" (Rosskam, 1981, 10). A dozen books of photographs were published in the 1935-1942 span in which the FSA operated (Goodwin, 1998, 274), and three of them drew solely from the FSA files: Archibald McLeish's Land of the Free (1938), Sherwood Anderson's Hometown (1940) and Richard Wright's Twelve Million Black Voices (1941). Among the other books published by FSA-affiliated photographers, some of them were widely circulated and/ or acclaimed such as An American Exodus (Dorothea Lange and Paul Taylor, 1939) and of course Let Us Now Praise Famous Men (James Agee and Walker Evans, 1941). Walker Evans's earlier book, American Photographs (1938) was compiled as the companion to the exhibition of his work at the Museum of Modern Arts. Such exhibits were also a main activity for the Historical Section whose task was not just to collect but, as part of the Information Division of the FSA, to broadcast information on the government's programs: "it was, as I have indicated before, to inform the widest possible segment of the American people about the rural problem that existed and about the governmental program established to meet it" (Rosskam, 1981, 10). The Historical Section was thus instrumental in setting up different kinds of exhibits. This ranged from actually putting together modest 30-picture travelling exhibits to providing material for the annual U.S Camera Salon as early as 1935 and 1936 (Hurley, 1972, 128), a venture through which Dorothea Lange's Migrant Mother or Arthur Rothstein's skull photographs became famous, to the more impressive 1938 Grand Central Palace Show and its posters on "How American People Live" (Curtis, 1989, 5 and Lugon, 2011, 125). By 1940 the FSA claimed a distribution of about 1,406 images every month to newspapers and periodicals that included popular magazines such as Time, Fortune, Life, Look, Today (Bezner, 1999, 6 and Stange, 1989, 111).

In this context-broadcasting information about 1930s America-the question of the visibility of the African American community has little been raised-with the notable exception of Natanson's The Black Image in the New Deal (1992). While Twelve Million Black Voices was undoubtedly an FSA initiative, at least an Edwin Rosskam initiative, it stands out as an exception in its endeavor to focus on African-Americans. Although there were a few exhibits dedicated to (re)presenting black life, notably Rosskam's exhibit "Farm Security Administration Aids the Negro Farmer" that displayed 36 photos of blacks at work or making the most of government assistance, those were meant to support and show the efficiency of federal programs and somewhat too deliberately "upbeat". When it comes to the more general traveling shows, Natanson contends that black representation was not visible.

The agency's first traveling exhibit of 1936, hailing the march from rural slums to

"new frontiers of farm independence", left black frontiers all but invisible, with only one black image among the exhibit's forty. Blacks are completely absent from a majority of the later shows, including the big nationalistic pitches in 1941 [...] When black images were included, representation tended to be quantitatively slight, qualitatively problematical, or both. (Natanson, 1992, 215) supporting federal programs; they were often designed with a simplistic-yet visually 
efficient-before/after approach. What's more, Natanson reports the complaints or reservation of local NSA officials, both South and North, with the use of pictures representing blacks for fear it might antagonize the intended (white) audience; as a result, "the greater the likely percentage of well-educated or reform-minded viewers in an exhibit audience, the greater the tendency for FSA exhibit designers to incorporate black content" (Natanson, 1992, 221). Press distribution went along the same lines. Newspapers and magazines were rarely provided with a choice of black pictures and when so, the images indulged "happy-go-lucky characterizations, along with [...] unqualified endorsement of white paternalism" (Natanson, 1992, 229). This hardly makes a case for an appraisal of the FSA's documentary photographs as a vehicle for exposing the truth of segregated America.

11 Yet the publication of Twelve Million Black Voices owes more to the FSA than a supply of ready-to-use photographs that African American writer and intellectual Richard Wright might have drawn from to achieve his own endeavor at exposing the African American truth to the eye of the American public. Indeed FSA employee Edwin Rosskam initiated the project, fought for its support by the FSA and arranged for the shooting of fresh material such as Photo 5 below.

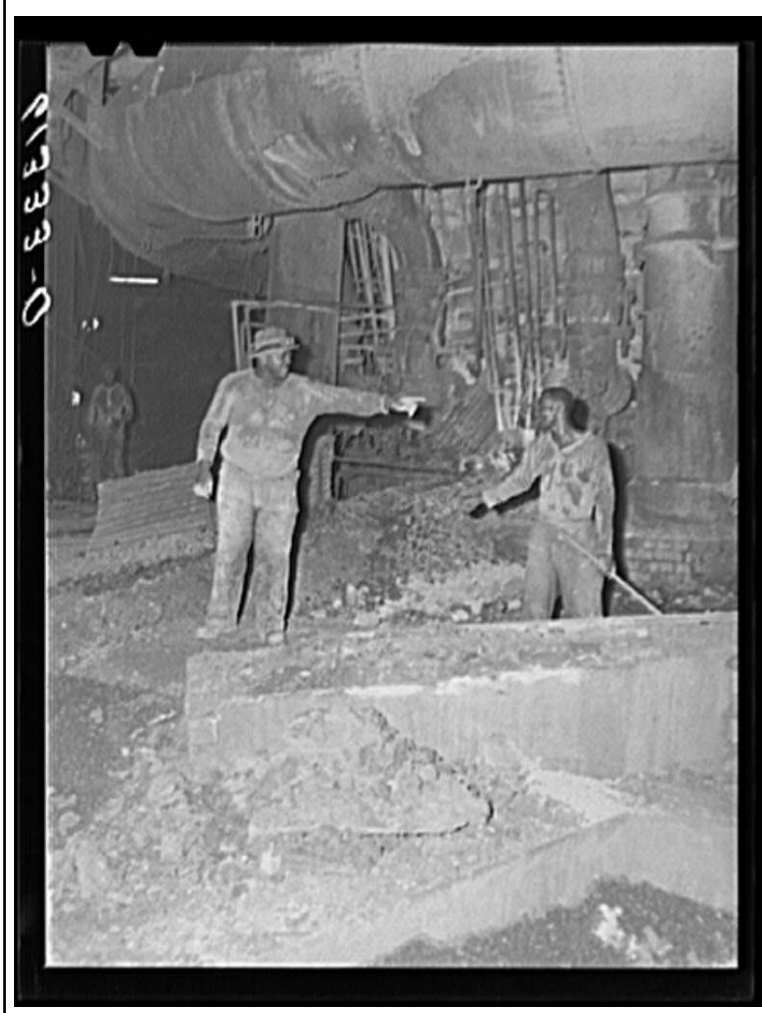

JOHN VACHON, NEgRO FOUNDRY WORKERS 


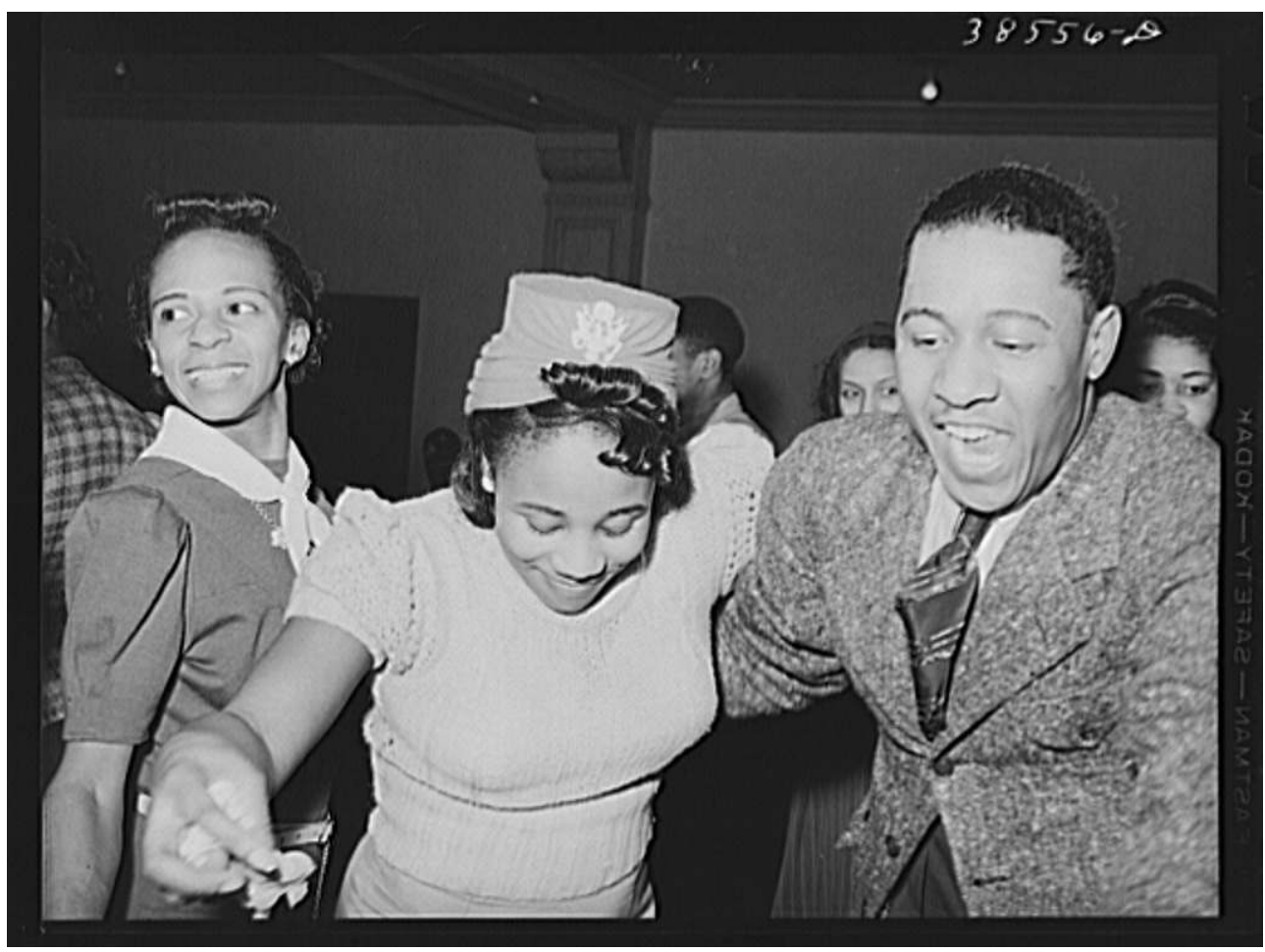

RUSSELL LEE, ROLLER SKATINg RINg

These two pictures from Twelve Million Black Voices are emblematic of an unseen sight of the lives of African Americans. The presentation of industrious urban workers and nonstereotyped recreational activities differs from the caricatured representations usually available, including through the FSA-sponsored exhibits and supply to the press. Interestingly enough, some of these pictures were specifically collected for the Twelve Million Black Voices project. Photo 5 above is part of Russell Lee's April 1941 trip to Chicago, a shooting assignment organized by Edwin Rosskam, that helps define the originality of the Twelve Million Black Voices project in the larger context of FSAsponsored photo books of the decade.

Richard Wright, once he agreed on the project, returned to Chicago in the summer of 1940 to collect material and conduct interviews; on that occasion he met with School of Chicago Professor Louis Wirth who provided him with a reading program in sociology and he exchanged with his friend, sociologist Horace Cayton. Cayton is one of the authors of Black Metropolis: A Study of Negro Life in a Nothern City, a landmark study on Chicago's South Side, that was to be published in 1945, with an introduction by Richard Wright-who was by then familiar with the sociological approach of the School of Chicago that fostered the celebrated black urban study. Wright had already been influenced by the works of Chicago sociologist Robert Park for the character development of Bigger Thomas. Native Son has been viewed as "Wright's case-study of Chicago" (Rodgers, 1997, 505). Wright's meeting with Rosskam in Washington in January 1941 to peruse through the FSA files concretely inaugurated the collaborative project and rich dialogue between the writer and the photo editor. In January 1941, Wright was able to provide Rosskam with an elaborate work in progress based on his research and readings since the previous summer, readings that were to be quoted in the preface. Upon that occasion, both men realized that the FSA existing material was too exclusively rural and Southern for Wright's comprehensive vision of black life in 
America. Rosskam's personal commitment to the project is evidenced by his relentless efforts: he convinced Stryker to support a new coverage with a more urban theme and setting and he went along with photographer Russell Lee on his two-week assignment in Chicago in April 1941. The correspondence between Wright and Rosskam, and between Wright and Horace Cayton (Stange, 2003, xvi), shows that whereas FSA photographers were used to working upon a "shooting script", ${ }^{9}$ it was Wright's text and the Wright-Rosskam correspondence that informed the Chicago photographic report. Cayton also accompanied Rosskam and Lee in the Chicago ghetto: "I don't know if many white men had the opportunity to see it the way we saw it", reported Rosskam (Stange, 2003, xvi). Wright, himself an accomplished amateur photograph (one of his pictures was to be included in the original publication of Twelve Million Black Voices), was able to provide insightful suggestions and the Chicago pictures taken with his text in mind were to form the core of the book's last two chapters. ${ }^{10}$ Consequently, text and pictures were genuinely interwoven before they met on the page.

The result is an original material presented in a book that was meant to be widely circulated ; Viking Press had been the publishing house of Steinbeck's Grapes of Wrath in 1939. Original because it displayed a reality that had rarely been shown as such and because one third was specifically collected for the book. Twelve Million Black Voices is composed of a preface and four chapters entitled: "Our Strange Birth" (focusing on the African American experience until the Civil War), "Inheritors of Slavery" (raising the issue of the isolation and determinism prevailing since the Civil War), "Death on the City Pavements" (moving the focus to the North following the Great Migration), "Men in the Making" (a brief call to arms). Such titles evidence the discursive project of the photo-text book. Rosskam used extracts of Wright's prose as titles to the photographs. In that sense, the text is not so much a commentary of the photographs, or the photos merely illustrative of the text, they collaboratively create an intended meaning. This is particularly striking with this chapter page and the meaning superimposed to the portrait by the Wright/ Rosskam collaboration : 


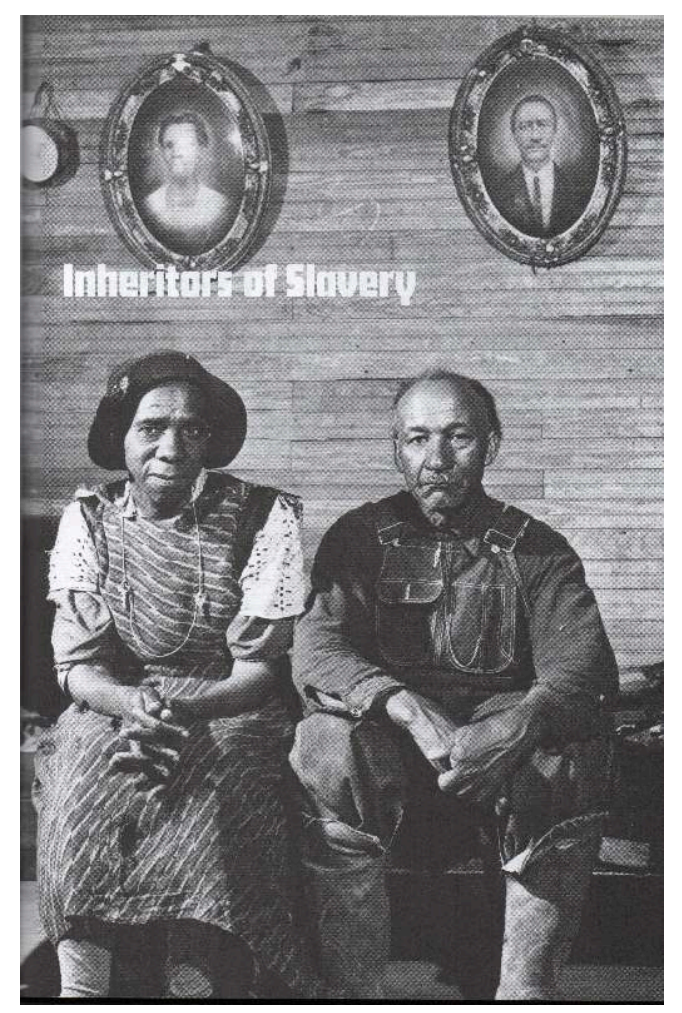

JACK DELANO, SHARECROPPER AND WIFE, CHAPTER PAgE INHERITORS OF SLAVERY

15

The page shows the way photo and text collaborate to signify a meaning, that is to say, in the African American tradition, to express a reality that is usually never viewed from a black perspective or interpreted by a black voice. Here the two sharecroppers are to be seen as descendants of slaves but only the words allow both an imposed connection between the contemporary despair and the past of slavery and a suggested difference with the white sharecroppers the audience was used to seeing and whose plight could be connected to the Great Depression. The original FSA caption, given by the photographer, "Negro preacher and his wife sitting under photos taken of them twenty years ago. They live in an old converted schoolhouse with two grandchildren. The rest of their children have moved out of the county", makes no such point, nor does the picture alone of course. ${ }^{11}$ In that sense, the truth offered in Twelve Million Black Voices is one devised by Wright's narrative to the point that Rosskam himself seems to have tried to avoid any link with a governmental aim. In the book he writes: "None of the photographs here reproduced was made for this book; they were taken by Farm Security photographers as they roamed the country during a five-year period on their regular assignments" (Wright, 1941, 149). Russell Lee and Rosskam himself could hardly be described as "roaming" in the Chicago South Side when they specifically shot more pictures for the book in April 1941 and the disclaimer, though hiding the truth about the completion of the project, ${ }^{12}$ seems to try and open a space for a black voice, one that resounds in the pronoun "we" used in the narrative, and conveys a yet unexposed truth about black life in America. 
Photography and the exposure of invisible Americans: which truth?

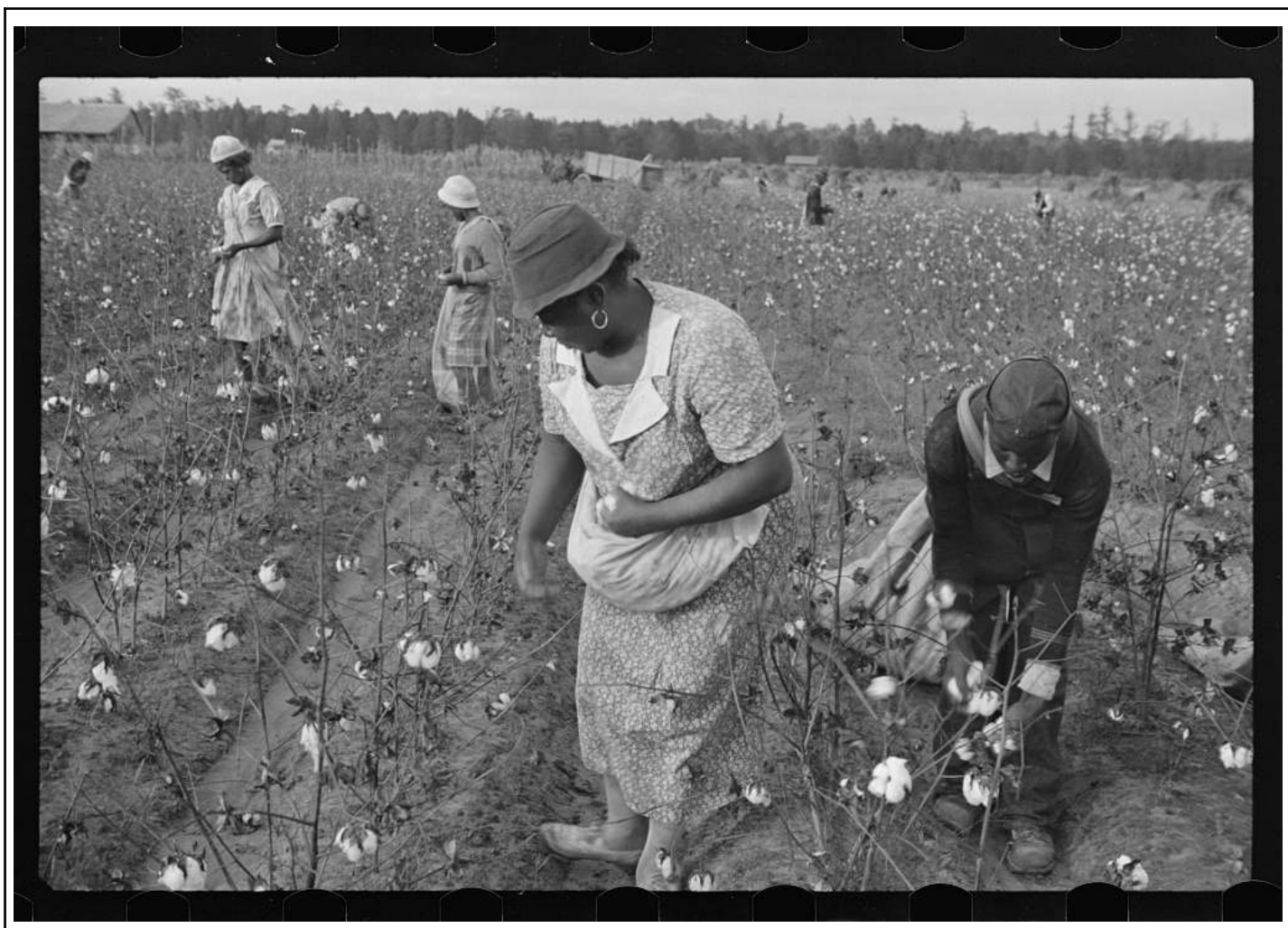

BEN SHAHN, COTTON PICKERS 


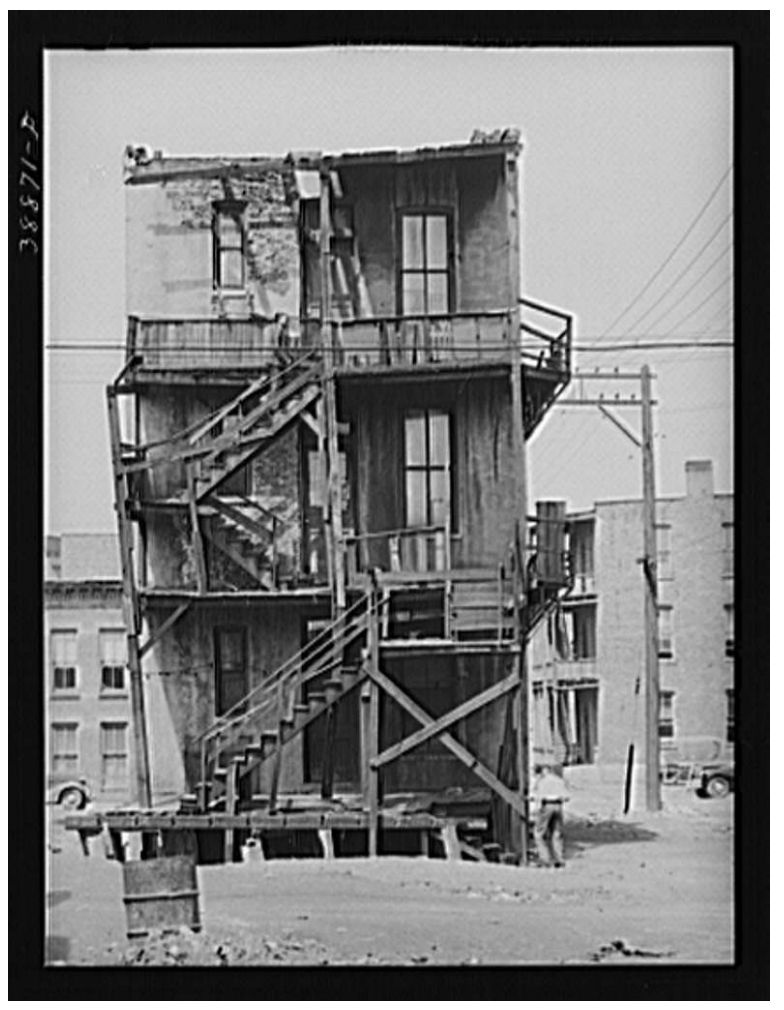

RUSSELL LEE, NEgRO DWELLINg

Wright's input in the selection of the photographs and the influence of his text on Rosskam's further editing work make it impossible to read Twelve Million Black Voices as a collection informed by Stieglitz's commitment to privilege "camera work" only. Whether FSA photography and 1930s documentary photography partake more of Lewis Hine's "social work" has often been agreed on. Olivier Lugon has convincingly argued that the protagonists of documentary photography, such as Stryker, actually used the reference to Hine in a retrospective construction of their own method. And while Lugon contends that they were not primarily influenced or consciously following in Hine's footsteps but chose him as a posteriori forefather, the filiation remains nevertheless relevant and serves an adequate understanding of documentary photography (Lugon, 2011, 357-360). This paper will not delve into the debate of art versus sociology or politics that surrounds the discussions about documentary photography. Such a debate has been usefully commented on by William Stott or more recently by Olivier Lugon. Yet it could be of interest to remind Newhall's definitions in his 1938 piece in Parnassus: beyond the debate of art versus sociology or politics, Newhall highlights the focus of documentary photography on poverty and the primary interest for the representation of "the homes and lives of the underprivileged" (Newhall, 1938, 5). In that sense, Twelve Million Black Voices fits into the framework of other photo-books of the time and echoes Lange and Taylor's (American Exodus, 1939) or Evans and Agee's commitments to report inequalities in America. What's more, Newhall identifies an emotional approach on the one hand, and the need for editorial addition on the other hand $:^{13}$

He will put into his camera studies something of the emotion which he feels toward the problem for he realizes that this is the most effective way to teach the public he is addressing. After all, is not this the root-meaning of the word 'document' (docere, "to teach") ? (Newhall, 1938, 5) 
Presentation is also a vital part of documentary still photography. The photograph is not valid as a document until it is placed in relationship to the beholder's experience. It is paradoxical that, although a photograph may be better than a thousand words, the addition of one or two words makes it even more concrete and forceful. (Newhall, 1938, 6)

Because of the deliberate emotion surfacing the photographs, and the denunciation of injustice repeated in image and words, the criticism most often encountered is that documentary photography, and the photo books it provided content to, convey a depressive feeling (Lugon, 2011, 127). Unsurprisingly this is also the most often encountered criticism against Twelve Million Black Voices: its gloomy representation of black life, or the over-sentimental tone. Indeed the "truth" exposed by Rosskam's and Wright's editorial and discursive choices follow Newhall's suggested biases, emotion and commentary. So if exposure to the "truth" of Black America was Rosskam's and Wright's aim, which truth came out?

18 The pictures of Southern and Northern life made visible to the greater public, not just in a local exhibit but through a national publication bearing the name of a best-selling author on the front page, were an unprecedented exposure to the African American reality for most readers. The target was undoubtedly a white readership likely to buy or come across the book. The reception of the book was mostly positive with Edwin Seaver declaring on a December 1941 radio program: "I know of no other book that brings home as clearly to the white reader what it means to be black in our country" (Kinnamon, 1993, 43). The Wright Papers at the Beinecke Rare Book and Manuscript Library (Yale University) contain a few folders of fan mail and press clippings from the 1941 publication praising the achievement in similar terms: "I want to thank you for contributing to my education", "this is the first time that the situation has been brought home to me". ${ }^{14}$ Two press clippings are worthy of attention: Harlem Renaissance Alan Locke wrote a piece in Opportunity in February 1942 suggesting that Wright's book fully answered the question "Who and What Is 'Negro' ?" ; Horace Cayton also wrote in his column in the Pittsburgh Courier (undated clipping) that "for every adjective Wright used, we have a table". The contemporary reading thus suggested the exposure of an unmediated truth and access to the reality of black life. The more critical and unconvinced pieces, however, highlight the choice of a "biased, depressing reality" (The Afro American, 22 November, 1941). ${ }^{15}$ This raises the question of a "biased" truth in Twelve Million Black Voices, just as it has often been brought up for the work or art of the Depression photographers, especially government-sponsored ones.

Still the "truth" of documentary photography remains a debate in spite of Margaret Bourke-White's assertiveness: "Whatever facts a person writes have to be colored by his prejudice and bias. With a camera, the shutter opens and closes and the only rays that come in to be registered come directly from the object in front of you" (quoted in Kazin, 1942, 495). Controversy over the "truth" of FSA photography arouse from the medium itself, even at the time, most famously over Arthur Rothstein's "skull photographs". It was discovered through the series the photographer had taken that he had moved the ox skull from its original spot to another location, a mere ten feet away, but whose cracked earth environment suggested a more severe drought and desolation. More useful to our perspective in this paper is the question of which truth is being conveyed by, not just the photographer's, but the editor's and narrator's of Twelve Million Black Voices. The deliberate choice of a partial truth that seems to be suggested 
by some of the readers and commentators may not be a flaw of Twelve Million Black Voices but its very essence.

The African American author devised the book with a very singular aim and a genuinely personal method: to awaken white consciousness with shock. Though there is no evidence of such a deliberate scheme in Wright's correspondence or interviews specifically for Twelve Million Black Voices, the similarity with Wright's achievement and strategy with Native Son is striking. In "How Bigger Was Born", Wright provides an interesting insight on why he wrote his 1940 novel Native Son after the publication of his first collection of short stories, Uncle Tom's Children in 1938 :

I had written a book of short stories which was published under the title Uncle Tom's Children. When the reviews of the book began to appear, I realized that I had made an awfully naïve mistake. I found that I had written a book which even bankers' daughters could read and weep over and feel good about. I swore to myself that if I ever wrote another book, no one would weep over it ; that it would be so hard and deep that they would have to face it without the consolation of tears. (Wright, 1940, 874)

In other words, Wright's strategy in his upcoming works, whether Twelve Million Black Voices (1941) or Black Boy (1945) would be to avoid the "consolation of tears". This may account for the predominantly gloomy choices in the photo book while Lee had also documented other aspects of Chicago's black life, most notably that of the middle-class. But any note of optimism was a bother to Wright's concern that this might alleviate the uneasiness of white readers discovering the grim black reality and undermine the shock he intended to trigger. This strategy was well understood by fellow Chicagoan Nelson Algren who wrote about Native Son on March 12, 1940:

It's the first book I ever came on wherein gruesomeness served a social purpose. [...] You hit me with something. You've hit me with something you've been holding behind your back all the while. But of course, when I come to, if I really am a communist in any real sense of the word at all, I'll be grateful for being slugged out of a coma. ${ }^{16}$

While Algren acknowledges the contemporary communist commitment to exposing the truth, he more importantly stresses the shock Wright's method was able to produce, even on an enlightened reader, for Algren was no stranger to the reality of Chicago's ghetto. The physical shock sought for is also expressed in this letter through a drawing of a man lying on the ground Algren added at the bottom of his letter, with the following comment: "What's the matter with that guy?", "That's Algren. Somebody slugged him with a book". Hence brutality and an uncompromised focus on grimnessincluding a lynching photograph-was Wright's modus operandi.

This is also reflected in Wright's correspondence with Book-of-the-Month Club Dorothea Canfield Fisher upon publication of Black Boy in 1944. While Wright's autobiography was chosen as a Book-of-the-Month Club selection, thereby promising a guaranteed success for the book, the board members demanded significant cuts and changes, among them the possibility for Wright to re-write the ending on a more positive note. Wright did not yield :

I fully understand the value of what you are driving at, but, frankly, the narrative as it now stands simply will not support a more general or hopeful conclusion. The Negro who flees the South is really a refugee; he is so pinched and straitened in his environment that his leaving is more an avoidance than an embrace. ${ }^{17}$

So more than once did Wright make the deliberate choice to focus on bleakness and hopelessness and offer no alternative reality of black life. Commentators have been 
critical of the writer's bias. Natanson has called attention to the absence of middle class representation, of irreverence and lightness in Twelve Millions Black Voices and to cases of Rosskam's "cleaning-up" of the photographs to fit Wright's point on urban misery. Indeed Natanson evidences the erasing of a young girl's tongue irreverently stuck out in the portrait of black family in the slum apartment to drive home a simplistic indictment (Natanson, 1992, 251).

Still, it can be argued, the "truth" about Black life in America that appeared in Twelve Million Black Voices was fresh, different and meaningfully shocking. Natanson reminds that the contemporary representation of the African American community more than often indulged in stereotyped images. He displays the August 9, 1937 issue of Life featuring a "black woman jamming a slice [of watermelon] into her mouth with one hand, holding a nursing baby with the other" (Natanson, 1992, 17-18). Such stereotypes are not present in Twelve Million Black Voices and without the comfort of familiar representations or the "consolation of tears" white readers were bound to be disturbed and/or educated. The book contains eight pictures of African American congregations at prayer, or reading or singing, a rare sight in segregated America and one that captures African American life well.

Beyond the immediate reception, the photographs (see photos $7 \& 8$ above) represent a twofold reality and epitomize a historical truth which appears connected not only to Great Depression reality but to American history at large: the rural Southern Black Belt and the urban Northern New Black Belt that emerged after the Great Migration. Richard Wright himself, born and raised in Mississippi, left for Chicago by way of Memphis in 1927 and was a product of the Great Migration. Between 1916 and 1919 an estimated half-million black southerners experienced the pull for labor of the "Northern fever" and push away from southern terror. In the 1920s another million followed (Grossman, 1989, 3-4). New York but also Chicago and its meat packing industry were destinations of choice, with fifty to seventy-five thousand black southerners relocating to Chicago between 1916 and 1919 (Grossman, 1989, 4). In that sense, cotton fields and urban slums are two symbolically adequate faces of 1930 s African American truth offered in Twelve Million Black Voices. Maren Stange gathered, in a 2003 photo book, the photographs of Chicago's South Side that had been shot by FSA photographers but had since remained buried in the Washington archives; in other words, her Bronzeville: Black Chicago in Pictures, 1941-1943 is the comprehensive counterpart to the selective and partial urban section of Twelve Million Black Voices. In her introduction, Stange appraises the work and legacy of FSA photographers in terms of their commitment to "truth". Indeed the focus on the "true" experience of the migrants in their work life and everyday activities is another source that has interested historians of late beyond demographic figures and economic data.

This is thus another understanding of "truth", in a historiographic perspective. The light shed on individual experience and community building in works about the Great Depression (Grossman, 1989, Cohen, 1990) gives a new relevance to Twelve Million Black Voices' varied portraits, as do the considerations on the scope of the Civil Rights Movement whose delineations are debated. The push to better account for African American agency has given credence to community-studies and opened the scope of the Civil Rights Movement to the grassroots protests of the Second World War, to the reforms and liberal consciousness of the New Deal Era (Stikoff, 1978) and even to the community building of the Great Migration (Hornsby, 2005, 456, 500). The historians' 
urge for a bigger picture to better appreciate "the evolving self-consciousness of African Americans and the shifting constraints that confronted them" (Lawson \& Payne, 1998, 110) is akin to Wright's own sense of the importance of his documentary book within a larger historical frame. Wright viewed Twelve Million Black Voices as the springboard for his ambitious project to write "the saga of the black nation in the United States" (Fabre, 1973, 234). Still, the editing work and addition of Wright's narrative raise the question of the staging of the truth in a crafted display whose understanding is influenced by the text.

\section{The narrative of a folk history: staging the truth ?}

According to Natanson's critical reading of Wright's contribution, "Wright wanted his reality in strictly black and white terms. Or, one might add, black, white, and red" (Natanson, 1992, 245). Of course Wright's vision of an oppressed people that was to rise against the oppressor, as expressed in the last chapter, "Men in the Making" is deeply influenced by his own communist commitment and protest culture: "We ask you to grant us nothing. We are winning our heritage, though the toll in suffering is great !" (Wright, 1941, 146). But this paper is more interested in the larger reading offered by the addition and weaving of a narrative into the sequence of pictures. For beyond the communist undertones, the wider goal is more ambitious: a Folk History of the Negro in the United States which was Twelve Million Black Voices' original subtitle. As already indicated, Rosskam borrowed from Wright's text to provide new captions to the photos. To the usual question of the photo / text balance in such photo books, the answer is here that of an authoritative narrative.

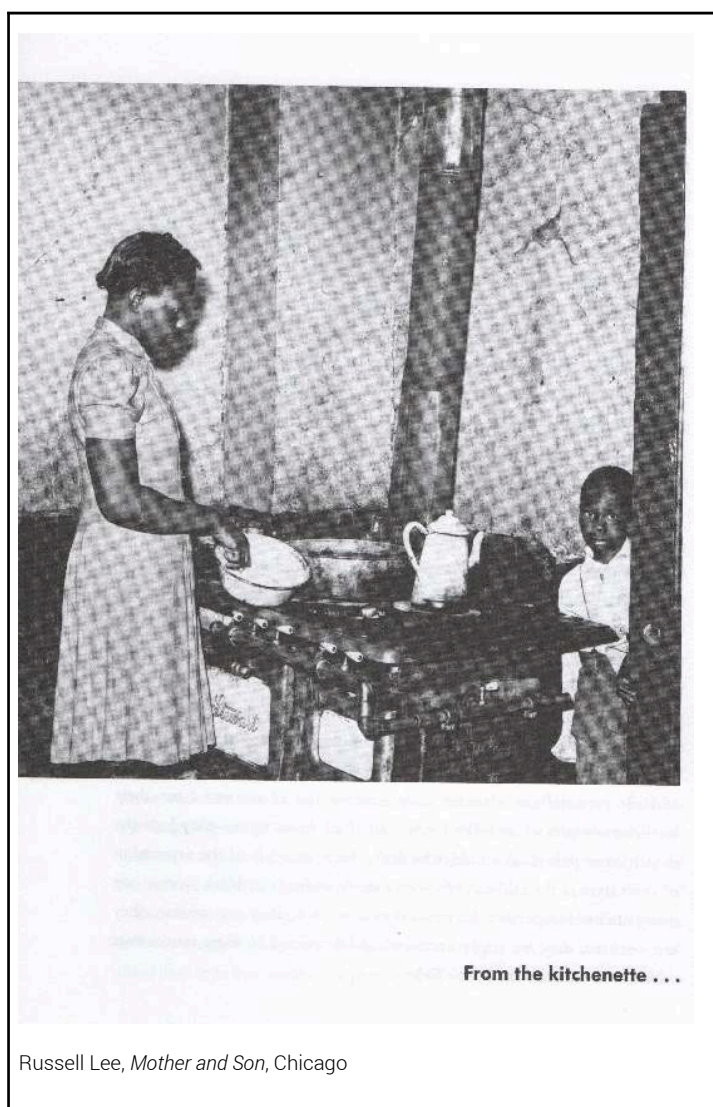




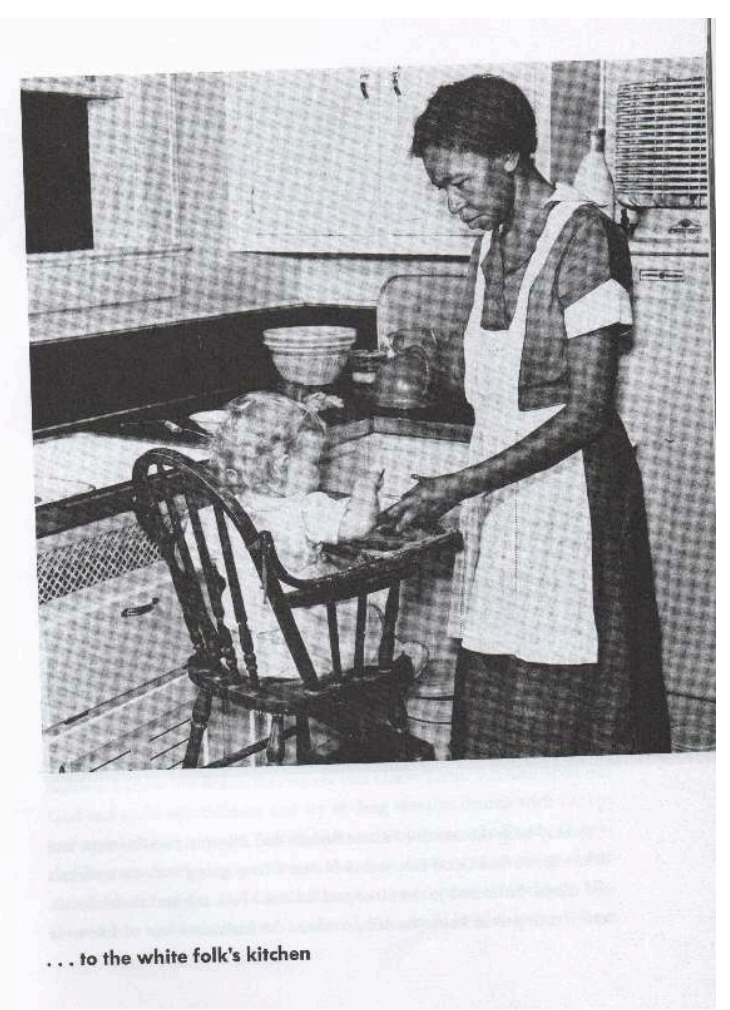

MARION WOLCOTT POST, MAID, GEORgIA

but an example, to be found on pages 132-133 of the photo book, of the collaboration between photo sequence, editing, and text. The editorial juxtaposition of the two photographs, taken in different contexts and not meant to reflect each other, encapsulates several aspects of America's racial question (inhumane living conditions on the fringe of and yet in permanent contact with the white world, continued servitude) while the text stresses the daily reminder of their inferior position and an exclusion many black workers were submitted to. When Trachtenberg argues that "American photographs are not simple descriptions but constructions, that the history they show is inseparable from the history they enact: a history of photographers employing their medium to make sense of their society" (Trachtenberg, 1990, xvi, my emphasis) and insists on the sequence rather on the isolated pictures, he may be offering a reading guide for Wright's endeavor as well.

welve Million Black Voices reconnects the African American experience with American history at large and, conversely, draws the link between that particular history and the reality of the Great Depression, more hardly felt by African American communities whose precariousness as sharecroppers or urban dwellers far preceded 1929. In that sense, Twelve Million Black Voices has a specific place and purpose in Great Depression photo books insofar as it reaches far beyond the immediacy of the crisis. Indeed Wright's project preceded the photo book as he reminded in this 1941 radio interview:

What I wanted to do was make an outline for a series of historical novels telescoping Negro history in terms of the urbanization of a feudal folk. My aim was to try to show in a foreshortened form that the development of Negro life in America parallels the development of all people everywhere. (Kinnamon, 1993, 44)

In other words, Wright had a demonstration in mind: to account for the origin of poverty in the urban ghetto by providing the perspective of living conditions in the rural South, which, in turn, were to be rooted in slavery and its aftermath. Hence the 
chronological organization of Twelve Million Black Voices that ends, once the slaverysegregation-Great Migration-Great Depression nexus has been constructed by both pictures and text in the first three chapters ("Our Strange Birth", "Inheritors of Slavery", "Death on the City Pavements"), in a final protest message ("Men in the Making") suggesting that urban centers are to be the locus of present and future struggles. Wright's research, visits to Chicago and the South, the successive drafts and how they served as guides of extensive photo shooting and photo selection evidence, as well as Rosskam's own insistence on Wright's primacy (Natanson, 1992, 244), all point out to a powerful and authoritative narrative.

Such a framework suffered no nuance or caution, so it seems, for the "truth" of the photographs was overlooked if need be. Both William Stott and Nicholas Natanson have devoted a development to Twelve Million's Black Voices inaccuracy, if not fraud, in the use of the photograph illustrating the "Our Strange Birth" Chapter that is to say the book's early chapter on the Middle Passage and slavery as the "weird and paradoxical birth" of an African American community (see Photo 11 below). After reminding the African slaves' contribution to the building and prosperity of the new nation, Wright concludes:

We black men and women in America today, as we look back upon scenes of rapine, sacrifice, and death, seem to be children of a devilish aberration, descendants of an interval of nightmare in history, fledglings of a period of amnesia on the part of men who once dreamed a great dream and forgot. (Wright, 1941, 27)

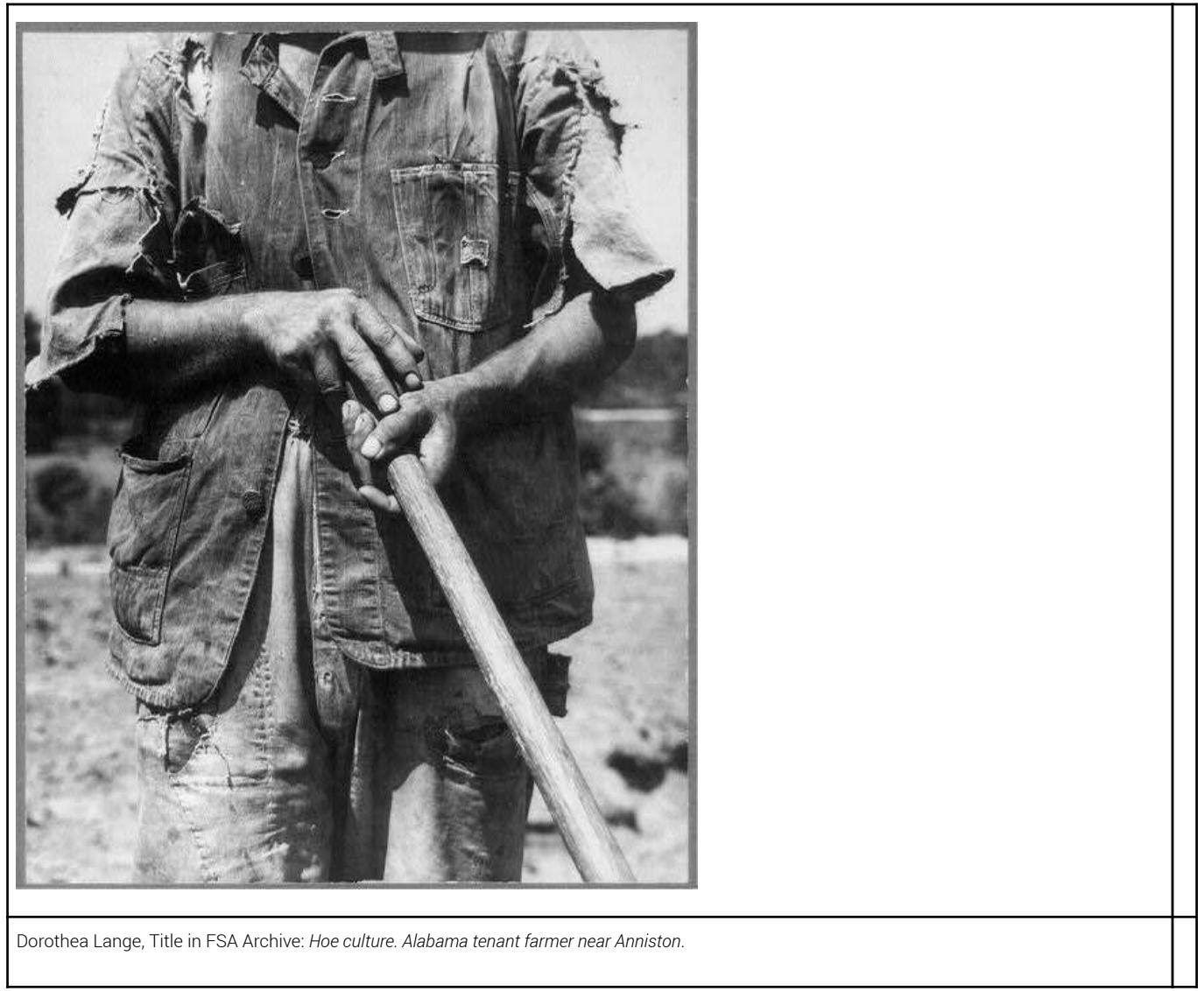




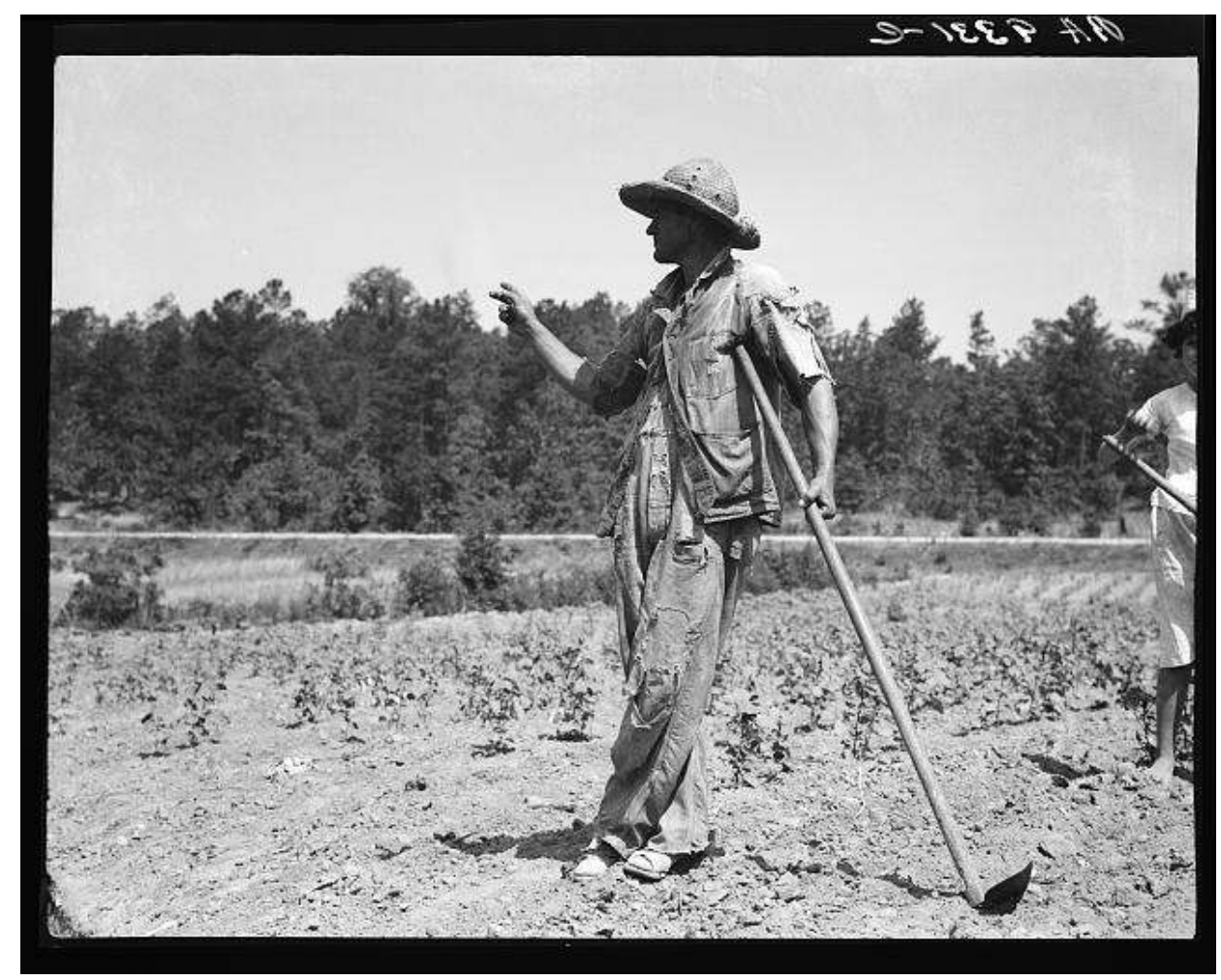

Dorothea Lange. Title in FSA Archive: Alabama tenant farmer near Anniston.

The illustration chosen by Rosskam seems adequate (Photo 11), focusing on the laboring hands of an Alabama sharecropper as symbols of the slaves' brought to grow the Southern colonies. Yet the FSA archive displays the whole series taken in 1936 by Dorothea Lange and leaves no doubt as to the fact that the tenant family was a white family. Photo 12 provides but one example from the archive; several other photographs portray the whole family at work in the fields and more than undoubtedly evidence that they were white. Rosskam did not even need to extensively re-crop Lange's photo which was already a close-up on the hands of the farmer. Still, "the use of a nonblack photograph for a vital black reference" (Natanson, 1992, 251) further thwarts the relation to truth and suggests the staging of visual elements to fit the commanding narrative.

Wright's text and its imposed meaning, however, may not be a reason to refuse the book's inclusion into the documentary photography tradition and practices if it is seen in the light Newhall retrospectively provided.

It seems to me that photography only becomes documentary when it is documented

[...] Documentary seems to me a matter of intent, not only on the part of the photographer but of the viewer as well. It is as much a matter of how the picture is used as how it is taken. (Newhall, 1984, 5-6)

In that sense the mediation of Richard Wright's narrative may intervene as the "documentation" needed in Newhall's view. But perhaps more than its Marxist bias, editing strategy, or possible respect of the spirit of documentary photography, the way Wright's narrative unfolds in relation to the American black truth is best understood through signifyin(g). Our commentary of Photo 6 has already suggested that photo and text collaborate to signify a new meaning, as does the African American tradition, in a context of oppression and danger, to express a self-determined meaning that might not be accepted and tolerated in a oppressive context. 

Voices. Those who have did offer interesting hints in terms of reading paradigms such as Jack B. Moore and his suggestion that Twelve Million Black Voices presents similarities not just with other photo books of the period but with film documentaries as well: the visual imagery combined with the impression of a speaking voice does remind of film techniques. John O'Reilly rather focused on the blues technique that he identifies in Wright's preaching tone and thus offers a folk reading that seems in keeping with Wright's "folk history" plan $^{18}$. In the end, while both documentary photography techniques and black tropes have been under consideration, they have rarely been reconciled. Their encounter, however, is allowed by the signifyin(g) approach here borrowed from African American scholar Henry Louis Gates.

Richard Wright's protest style is best epitomized by the question he famously asked in his best-selling autobiography: "Could words be weapons ?" (Wright, 1945, 237). And while it is usually associated to the writer's Marxist convictions and perspective, Wright's famous phrase adequately describes what signifyin(g) has always meant for African Americans in their oppressing environment: the possibility to "fight back with words", to play on the figurative meaning of what they were saying, to be the trickster figure that makes sense. And although Wright does not play on double entendre or practice the "repetition with a difference" that was identified by Gates as a technique to re-appropriate a reality, a literary reference, a story, he is indeed a trickster figure in Twelve Million Black Voices. He is the trickster (Gates's Signifyin(g) Monkey) who tells the story on his own terms and subverts the meaning (of American history) to his profit and to the detriment of the ruler and oppressor (Gates's lion figure). In the same way as W.E.B. DuBois first accomplished a black and Marxist rewriting of Reconstruction history in Black Reconstruction (1935), Richard Wright sketched his own version of a revisionist African American history wherein the black protagonists are integrated within the scope of America's destiny, past and present, and empowered by their ability to take command of the we-narrative and future action. True, traces of the contemporary thinking that slavery had hurt and damaged the African American community seem to surface in some of Wright's statements:

Three hundred years are a long time for millions of folk like us to be held in such subjection, so long a time that perhaps scores of years will have to pass before we shall be able to express what this slavery has done to us, for our personalities are still numb from its long shocks. (Wright, 1941, 31)

The suggestion of a "numb" community, unable to react to and fully understand the pain inherited, along with the accompanying picture of a row of field workers carrying their hoes on their way to work reinforces an inescapable connection to slavery. 


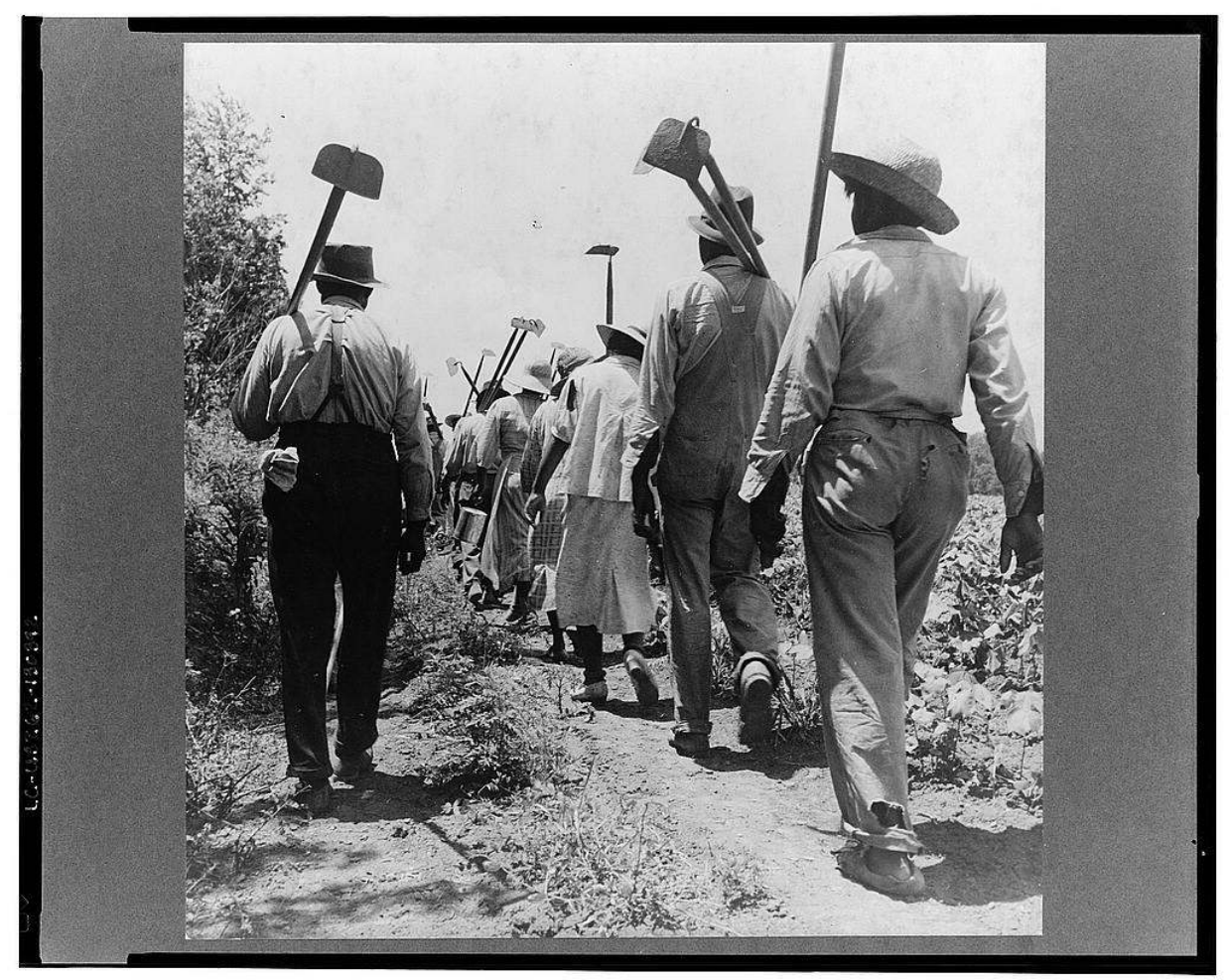

DOROTHEA LANGE, COTTON HOERS gOINg TO WORK, MISSISSIPPI

39 The figures on the photographs have their backs turned to the camera and this may reinforce the impression that these impersonal African American figures still bear the weight of a past tragedy. This, with Wright's acknowledgement in his preface that he deliberately excluded any mention and representation of the African American leadership, the "talented tenth" for they were only a too rare exception, may explain why this was the most criticized passage of Twelve Million Black Voices. It does remind of-or rather announces-Elkin's controversial figure of Sambo, the African slave reduced by brutality to a dependent and passive individual, an Uncle Tom, unable to resist.

Still the folk perspective and empowerment at play in the narrative, in other words the possibility for an agency and a rich autonomous culture displayed in the text, forcefully counterbalance the images of hard work, blank expressions and church devotion. The folk culture that lies at the heart of the narrative is one of revolt and agency, Wright also makes clear:

\begin{abstract}
We stole words from the grudging lips of the Lords of the Lands, who did not want us to know too many of them or their meaning. And we charged this meager horde of stolen sounds with all the emotions and longings we had; we proceeded to build our language in inflections of voice, through tonal variety, by hurried speech, in honeyed drawls, by rolling our eyes, by assigning to common, simple words new meanings, meanings which enabled us to speak of revolt in the actual presence of the Lords of the Lands without their being aware! (Wright, 1941, 40)
\end{abstract}

41 The disguised rebellion, subverted reverence and ability to fight with an elaborate culture and strategy are all revealed in this passage but were not to be central in historiography until Genovese's Roll Jordan Roll (1974). In that perspective of a folk culture both revealed and enacted in Twelve Million Black Voices, one is able to seize the way Wright may be signifyin(g) on the pictures displayed to support his thesis that African American history must be included within the larger frame of American 
History. For instance, the numerous pictures of slums, empty lots, derelict apartments that are typical of 1930s Depression imagery take on a different meaning when posted next to Wright's contention that:

For years we watch the timid faces of poor white peasants-Turks, Czechs, Croats, Finns, and Greeks-pass through this curtain of smoke and emerge with the sensitive features of modern men. But our faces do not change [...] Of a morning, years later, we pick up [the newspaper] and see that some former neighbors of ours, a Mr. and Mrs. Klein or Murphy or Potaci or Pierre or Cromwell or Stepanovich and their children-kids we once played with upon the slag piles-are now living in the suburban areas, having swum upstream through the American waters of opportunity into the professional classes. (Wright, 1941, 102)

If the pictures do remind the 1940s reader of Jacob Riis's New York tenements photographs and the contemporary reader of random 1930s Hooverville-style pictures, Wright's text turns them into evidence of the African American's exclusion from the great American narrative. The slums are not a first landing step as they may have been for $19^{\text {th }}$ Century immigrants or a temporary fallout of a Depression era, they are the dwellings of Black Americans without any hope of an upcoming improvement. The pictures alone could not suffice to illustrate that the black experience is both the same as that of other Americans and strikingly different, both part of and on the margin of the American story. The narrative subverts the "truth" of these Depression pictures whose original purpose was to document the need for and the effects of New Deal relief policies. The narrative creates a new "truth" to the origin of the misery, grimness and poverty-not the Great Depression, universally experienced by Americans but the results of centuries of oppression and exclusion, of a nation's choice to ignore the faces and voices of twelve million Americans.

\section{Conclusion}

On the eve of the 1941 Pearl Harbour attack, in the context of a mounting threat for the Western nations and America's reluctant yet inescapable leadership, the book was not just well received by the critics, readers and fellow African American intellectuals. ${ }^{19}$ It also led to the opening of an FBI investigation on Wright on sedition motives (Shiffman, 2007, 455), possibly because it questioned the great American narrative and encouraged black citizens to move "into the sphere of conscious history" and "cross the line" (Wright, 1941, 147). The effectiveness of Twelve Million Black Voices as a powerful gesture of empowerment and activism is reckoned by Ralph Ellison :

The book makes me feel a bitter pride; a pride which springs from the realization that after all the brutalization, starvation and suffering, we have begun to embrace the experience and master it. And we shall make of it a weapon more subtle, more effective than a fighter plane $!^{20}$

The comment of Ellison, an African American writer who was to write Invisible Man in 1952 is an apt quotation to end this discussion of Twelve Million Black Voices on the conclusion that it achieved the intended shock for the reader, succeeded in being a weapon of protest rhetoric and a powerful expression of black agency. It was able to draw from 1930s documentary photography, both in content and strategy, and foster the interesting encounter of the New Deal photographers and photo editors with a radical African American perspective to construct the truth of African American 
experience from the photographed reality of 1930s America, a much needed material for the Civil Rights fights that were to come in the next decade.

\section{BIBLIOGRAPHY}

\section{References}

AGEE, James \& Walker EVANS, Let Us Now Praise Famous Men, Boston, Houghton Mifflin Company, 1941.

ANDERSON, Sherwood, Hometown, New York, Alliance Book Corporation, 1940.

BEZNER, Lili Corbus, Photography and Politics in America: From the New Deal into the Cold War, Baltimore Md, London, The Johns Hopkins University Press, 1999.

CAYTON, Horace R. and DRAKE, Saint Clair, with an introduction by Richard WRIGHT, Black Metropolis: A Study of Negro Life in a Northern City, New York, Harcourt, Brace and Company, 1945.

COHEN, Lizabeth, Making a New Deal: Industrial Workers in Chicago, 1919-1939, Cambridge, New York, Cambridge University Press, 2008 [1990].

CURTIS, James, Mind's Eye, Mind's Truth: FSA Photography Reconsidered, Philadelphia, Temple University Press, 1989.

ELLISON, Ralph, Invisible Man, New York, Vintage Books, Random House, 1972 [1947].

DUBOIS, W.E.B., Black Reconstruction in America, an essay toward a history of the part which Black folk played in the attempt to reconstruct democracy in America, 1860-1880, New York, Oxford University Press, 2007 [1935]

ELKINS, Stanley, Slavery: A Problem in American Institutional and Intellectual Life, Chicago, University of Chicago Press, 1976 [1959].

EVANS, Walker, American Photographs: Seventy-Fifth Anniversary Edition, Museum of Modern Art, 2012 [1938].

FABRE, Michel, The Unfinished Quest of Richard Wright (Trans. Isabel Barzun), New York, William \& Morrow, 1973.

GATES, Henry Louis Jr., The Signifyin(g) Monkey, A Theory of Afro-American Literary Criticism. New York \& Oxford, Oxford University Press, 1988.

GENOVESE, Eugene D., Roll Jordan Roll: The World Slaves Made, New York, Pantheon Books, 1974.

GODINE, Amy, "Notes Toward a Reappraisal of Depression Literature”, Prospects, An Annual of American Cultural Studies, $\mathrm{n}^{\circ}$ 5, 1980, 197-239.

GOODWIN, James, "The Depression Era in black and white: four American photo-texts", Criticism, Volume XL, n² 2, 1998, 273-307. 
GROSSMAN, James, Land of Hope: Chicago, Black Southerners, and the Great Migration, Chicago, University of Chicago Press, 1989.

HORNSBY, Alton, ed., A Companion to African American History, Malden MA, Blackwell Pub., 2005. HURLEY, Jack F., Portrait of a Decade, Roy Stryker and the Development of Documentary Photography in the Thirties, Baton Rouge, Louisiana State University Press, 1972.

KAZIN, Alfred, On Native Grounds, An Interpretation of Modern American Prose Literature, New York, Reynal \& Hitchcock, 1942.

KINNAMON, Kenneth ed., Conversations with Richard Wright, Jackson, University Press of Mississippi, 1993.

LANGE, Dorothea and Paul TAYLOR, An American Exodus ; a record of human erosion in the Thirties, extended edition, New Haven, Yale University Press / Oakland Museum, 1969, [1939]

LAWSON, Steven F. and Charles PAYNE, Debating the Civil Rights Movement, 1945-1968, Introduction by James PATTERSON, Lanham Md, Rowman and Littlefield Publishers, 1998.

LUGON, Olivier, Le Style documentaire d'August Sander à Walker Evans, 1920-1945, Paris, Editions Macula, 2011.

MACLEISH, Archibald, Land of the Free, New York, Harcourt, Brace and Company, 1938

MOORE, Jack B, “The Voice in 12 Million Black Voices”, Mississippi Quarterly, Volume XLII, No. 4, 415-24.

NATANSON, Nicholas, The Black Image in the New Deal: The Politics of FSA Photography. Knoxville, University of Tennessee Press, 1992.

NEWHALL, Beaumont, "Documentary Approach to Photography", Parnassus, Volume X, $\mathrm{n}^{\circ} 3$, March 1938, 2-6.

---, "A Backward glance at documentary" in FEATHERSTONE, David ed., Observations: Essays on Documentary Photography, Carmel, California, The Friends of Photography, 1984, 1-6.

REILLY, John M., "Reconstruction of Genre as Entry into Conscious History", Black American Literature Forum, Volume XIII, Nº 1, Spring 1979, 3-6.

---, "Richard Wright preaches the Nation: 12 Million Black Voices", Black American Literature Forum, Volume XVI, n³, Autumn 1982, 116-119.

RODGERS, Lawrence R., Canaan Bound: the African American Great Migration Novel, Chicago, University of Illinois Press, 1997.

ROSSKAM, Edwin, “Not Intended for Framing: the FSA Archive”, Afterimage Volume VIII, $\mathrm{n}^{\circ} 8$, March 1981, 9-11.

SHIFFMAN, Dan, "Richard Wright's 12 Million Black Voices and World War II-era Civic Nationalism", African American Review, Volume XLI, Issue 3, 1 October 2007, 443-458.

SITKOFF, Harvard, A New Deal for Blacks, The Emergence of Civil Rights as a National Issue, Volume One: The Depression Decade, New York, Oxford University Press, 1978.

SMITH WHATLEY, Virginia, "Image Text and Voice in the Wright-Rosskam Photographic Text", Obsidian II. 8.2, Fall-Winter 1993, 1-27.

STANGE, Maren, Symbols of Ideal Life, Social Documentary Photography in America, 1890-1950, New York, Cambridge University Press, 1989. 
---, and LEE, Russell \& ROSSKAM Edwin (Photographs), Bronzeville: Black Chicago in Pictures, 1941-1943, New York, New Press, 2003.

STOTT, William, Documentary Expression and Thirties America, Chicago \& London, The University of Chicago Press, 1986 [1973].

TRACHTENBERG, Alan, Reading American Photography: Images as History. Matthew Brady to Walker Evans, New York, Hill and Wang, 1990, [1989].

TUGWELL, Rexford G., Thomas MUNRO and Roy E. STRYKER, American Economic Life and the Means of its Improvement, New York, Harcourt, Brace and Company, 1925.

WRIGHT, Richard, 12 Million Black Voices: A Folk History of the Negro in the United States. Photo direction by Edwin ROSSKAM, New York, Thunder's Mouth Press, 2002 [New York, Viking Press, 1941].

---,"How Bigger Was Born” (1940) and Black Boy (1945) rep. in RAMPERSAD, Arnold ed., Richard Wright, Early Works, New York, Library of America, 1991, 853-881.

\section{List of Photographs}

The photographs used in this article come from Twelve Million Black Voices-with the exception of photographs $2 \& 12$-and page numbers below are those of Twelve Million Black Voices [2002]. The titles chosen by Edwin Rosskam from Richard Wright's text, printed by the photograph or provided in the book index (Wright, 1941, 149-152), have been kept in this paper although they may differ from the original titles of the FSA fund ; both titles are provided in the following list. All photographs are available on the Library of Congress website. As US Government work, they are not copyrighted and their reproduction here is accordance with the Rights and Restrictions Information.

(http://www.loc.gov/rr/print/res/071_fsab.html).

(1) We Plow and Plant Cotton. Dorothea Lange, The cotton sharecropper's unit is one mule and the land he can cultivate with a one-horse plow. Greene County, Georgia, 1937, p. 27, Library of Congress, Prints \& Photographs Division, FSA/OWI Collection, [LC-DIG-fsa-8b15388], http://www.loc.gov/ pictures/item/fsa2000001598/PP/ (Accessed 25 February 2015)

(2) Migrant Mother. Dorothea Lange, Destitute peapickers in California ; 32 year old mother of seven children, February 1936, Library of Congress, Prints \& Photographs Division, FSA/OWI Collection, [LC-USF34-9058-C], http://www.loc.gov/rr/print/list/128_migm.html (Accessed 25 February 2015)

(3) Original 1941 Cover of Twelve Million Black Voices as published by Viking Press. This book cover was retrieved from Ursus Books Rare Books Library's website: http://www.ursusbooks.com/ item140665.html (Accessed 23 February 2015)

(4) Negro Foundry Workers. John Vachon, Steel mill workers, Bethlehem company, Sparrows Point, Maryland, 1940, p. 119, Library of Congress, Prints \& Photographs Division, FSA/OWI Collection, [LC-USF34-061333-D], http://www.loc.gov/pictures/item/fsa2000041960/PP/ (Accessed 25 February 2015)

(5) Roller Skating Ring. Russell Lee, Having fun at roller skating party at Savoy Ballroom, Chicago, Illinois, 1941, p. 127, Library of Congress, Prints \& Photographs Division, FSA/OWI Collection, [LCUSF34-038556-D], http://www.loc.gov/pictures/item/fsa2000019928/PP/ (Accessed 25 February 2015) 
(6) Sharecropper and Wife. Jack Delano, Negro preacher and his wife sitting under photos taken of them twenty years ago. They live in an old converted schoolhouse with two grandchildren. The rest of their children have moved out of the county. Heard County, Georgia, 1941, p. 29, Library of Congress, Prints \& Photographs Division, FSA/OWI Collection, [LC-USF34-043918-D], http://www.loc.gov/ pictures/item/fsa2000025460/PP/ (Accessed 25 February 2015)

(7) Cotton Pickers. Ben Shahn, Picking cotton on Alexander plantation. Pulaski County, Arkansas, 1935, p. 53, Library of Congress, Prints \& Photographs Division, FSA/OWI Collection, [LCUSF3301-006217-M2], http://www.loc.gov/pictures/item/fsa1997017002/PP/ (Accessed 25 February 2015)

(8) Negro Dwelling. Russell Lee, Back of multi-family dwellings rented to Negroes. Chicago, Illinois, 1941, p. 91, Library of Congress, Prints \& Photographs Division, FSA/OWI Collection, [LC-USF34-038871D], http://www.loc.gov/pictures/item/fsa2000020243/PP/ (Accessed 25 February 2015)

(9) Mother and Son. Russell Lee, Corner of kitchen of apartment rented to Negroes. Chicago, Illinois, 1941, p. 32, Library of Congress, Prints \& Photographs Division, FSA/OWI Collection, [LC-USF34-038777D], http://www.loc.gov/pictures/item/fsa2000020152/PP/ (Accessed 25 February 2015)

(10) Maid, Georgia. Marion Wolcott Post, Negro domestic servant. Atlanta, Georgia, 1939, p. 133, Library of Congress, Prints \& Photographs Division, FSA/OWI Collection, [LC-USF34-T01-051738D], http://www.loc.gov/pictures/item/fsa2000032138/PP/ (Accessed 25 February 2015)

(11) Dorothea Lange, Hoe culture. Alabama tenant farmer near Anniston, 1936, p. 9, Library of Congress, Prints \& Photographs Division, FSA/OWI Collection, [LC-USZ6-1028], http:// www.loc.gov/pictures/item/fsa1998021627/PP/ (Accessed 25 February 2015)

(12) Dorothea Lange, Alabama tenant farmer near Anniston, Alabama, 1936, Library of Congress, Prints \& Photographs Division, FSA/OWI Collection, [LC-USZ62-70695], http://www.loc.gov/ pictures/item/fsa1998021630/PP/ (Accessed 25 February 2015)

(13) Cotton Hoers going to Work, Mississippi. Dorothea Lange, These cotton hoers work from 6 a.m. to 7 p.m. for one dollar near Clarksdale, Mississippi, 1937, p. 31, Library of Congress, Prints \& Photographs Division, FSA/OWI Collection, [Library of Congress, Prints \& Photographs Division, FSA/OWI Collection, [LC-USZ62-70695], http://www.loc.gov/pictures/item/fsa2000001395/PP/ (Accessed 25 February 2015)

\section{NOTES}

1. The title provided is that of Twelve Million Black Voice, either printed next to the photograph or in the book index. In both cases, it often differed from that given by the photographer and kept in the FSA Archive. This will be commented on. For full titles, credits and copyright, see List of Photographs at the end of the article.

2. "If I could do it, I'd do no writing at all here. It would be photographs; the rest would be fragments of cloth, bits of cotton, lumps of earth, records of speech, pieces of wood and iron, phials of odors, plates of food and of excrement" (Agee, 1941, 13).

3. The Resettlement Administration, newly-established in 1935, became the Farm Security Administration in 1937 ; the Historical Section (as the photographic unit was called) disappeared in 1942 when it was merged into the Office of War Information, the OWI (Natanson, 1992, 3n3).

4. Gordon Park was the only African American photographer on the team and joined the unit only shortly before it was merged into the OWI.

5. "Roy was our boss and he didn't let us forget it. He was the inventor of our maverick outfit, and he defended it with every bureaucratic weapon against all enemies, real or imagined, lest 
they threaten our budget, our independence, and our God-given right to continue as he, Roy, pleased" (Rosskam, 1981, 9). On the rather blurry definition of the Historical Section's tasks, see Lugon, 2011, 119-120.

6. It is now known that Florence Owen Thompson, the "migrant mother" in Dorothea Lange's celebrated 1936 portrait, was in fact from Native American descent.

7. This is the first edition cover of Twelve Million Black Voices: A Folk History of the Negro in the United States as originally published by Viking Press in 1941. A reissue of the book is currently available, published by Thunder's Mouth Press in 1988. All page numbers in this paper refer to the 2002 Thunder's Mouth Press new edition (with an added foreword by Professor Noel Ignatiev and introduction by Professor David Bradley. The reissue, it should be noted, deletes the subtitle "A Folk History of the Negro in the United States". According to Goodwin (1998, 281, n12) photographs have been repositioned or substituted in several instances and the photograph taken by Richard Wright himself has been removed. It should be added that the cover picture has changed several times over the years, depending on the edition. This book cover was retrieved from Ursus Books Rare Books Library's website : http://www.ursusbooks.com/item140665.html (Last accessed on 23 January 2015).

8. The African American population amounted to $9.8 \%$ of the American population in 1940 (Natanson, 1992, 66).

9. "Before a photographer went into a region, he was given all the information that Stryker could muster concerning the area, its people, its economy, and even politics and social mores. Often the photographer would have a list of specific pictures to look out for. Such lists later became elaborate 'shooting scripts"' (Hurley, 1972, 56).

10. This analysis on the Rosskam/Wright collaboration and on the Chicago report relies on information found in Goodwin (1998, 282), Stange (2003, xv-xviii), Natanson (1992, 144-145) and Fabre (1973, 209 \& 232-233). David Bradley, in the 1988 edition of Twelve Million Black Voices, also reminds that Wright, a native of Mississippi, went back to the South for the first time in twentyfive years during the preparation of the book (xvii).

11. In his 1981 interview in AfterIMage, Rosskam details the process through which FSA photographers on the road would send their rolls back to Washington, receive their prints back in their hotels and carefully label each of the prints before mailing them back to Washington (Rosskam, 1981, 10).

12. Though biographical evidence and correspondence show that Lee and Rosskam went to Chicago with a specific aim (the Twelve Million Black Voices project), they did collect over a thousand pictures that enriched the FSA files while less than twenty made it into the book.

13. Newhall's 1938 "Documentary Approach to Photography" is one of the defining pieces of documentary photography. For more founding texts by photographers of the period (Dorothea Lange or Berenice Abbott), see Lugon, 2011, 19.

14. Richard Wright Papers, The James Weldon Johnson Memorial Collection of African American Arts and Letters (JWJ) Beinecke Rare Book and Manuscript Library, Yale University, Box 63, Folder 740. Thereafter quoted as Beinecke.

15. Beinecke, Box 63, Folder 741.

16. Letter from Nelson Algren to Richard Wright, 12 March, 1940, Beinecke, Box 93, Folder 1167.

17. Letter from Richard Wright to Dorothea Fisher, 6 July, 1944, Beinecke, Box 97, Folder 1333.

18. Also of interest is Virginia Whatley Smith's article on image, text and voice in Twelve Million Black Voices.

19. According to Maren Stange, "reviews were largely positive" and the photo book became "an instant Bible" for African American photographer Gordon Parks while it was taught in creative writing courses by Langston Hughes (Stange, 2003, xxiv). For the reception of Twelve Million Black Voices in the press, also see Natanson, 254-5.

20. Letter from Ralph Ellison to Richard Wright, 3 November 1941, Beinecke, Box 97, Folder 1314. 


\section{ABSTRACTS}

Twelve Million Black Voices is a 1941 collection of photographs, selected from the Farm Security Administration files by FSA-employed Edwin Rosskam and accompanied by Richard Wright's texts. This paper examines the specificity of Twelve Million Black Voices within the frame of American documentary photography. The first part of this paper considers the original place of a phototext book on black life in a decade of "documentary literature" (Kazin, 1942, 493). The second part raises the question of the social, economic and political reality exposed by the widespread publication of photographs of -invisible- black Americans. Ultimately the paper will extend the reflection on "truth" in the narrative. A "folk history" is carefully crafted, or perhaps staged, by the weaving of text and photographs. This paper thus strives to articulate the recording of 1930s reality and the exposure of racial discrimination, the aesthetic vision of FSA photographers and the protest narrative unfolded by Wright by discussing the singular way Twelve Million Black Voices manages to signify the truth of the African American reality.

Twelve Million Black Voices, recueil de photographies dont Richard Wright signe les textes en 1941 est l'alter ego du célèbre Let Us Now Praise Famous Men de James Agee: l'ouvrage est animé du même esprit documentaire des années trente, émane de l'administration fédérale du New Deal et s'appuie sur le travail d'artistes engagés qui œuvrèrent à révéler par la photographie leur vérité sur une Amérique cachée. Twelve Million Black Voices offre à voir les visages de l'ombre et la vie secrète d'Américains que la ségrégation rendait invisibles au regard blanc.

En marge de l'exposition ou révélation photographique d'une vérité supposément brute, Wright rédige une histoire revisitée de l'Amérique (noire) à la première personne du pluriel. La stratégie de réappropriation du discours, de l'histoire, de la destinée de la communauté afro-américaine mise en lumière dans cet article permet de contribuer aux nouvelles approches sur la photographie documentaire.

\section{INDEX}

Mots-clés: Photographie documentaire, Grande Dépression, Farm Security Administration, Richard Wright, Etudes afro-américaines, protest literature, signifyin(g)

Keywords: Documentary Photography, Great Depression, Farm Security Administration, Richard Wright, African American Studies, protest literature, signifyin(g)

\section{AUTHOR}

\section{LAURENCE COSSU-BEAUMONT}

Université Paris 3 Sorbonne Nouvelle 